\title{
右利き，左利きの考え方
}

\author{
吉田 友英

\section{The view of a right-handed and a left-handed person}

\author{
Tomoe Yoshida \\ Toho University Medical Center Sakura Hospital, Department of Otolaryngology
}

\section{はじめに}

“あなたは何利きですか？”と聞かれるとほと んどの人は “右利き”と答える。人間の $90 \%$ は右 利きであるといわれているが，右利き，左利きと いうことを，日頃意識していることは少ない。小 学生に右・左を教えるときは，お茶碗を持つ手が 左手，お箸を持つ手が右手と言われることが多 い。これは, 右手が利き手であるという大前提の 上の説明である。右, 左とどちらが優位かは別と して, 現在衣食住などの日常はほとんどが右利き にとって生活しやすいようにできている。

一般的には, 右と左では, 左の方が劣位に扱わ れていることが多い。左遷, 左前, 左巻き……な ど。いつから右・左の区別がついてきたのであろ うか。人類は生き残りをかけた戦さなどの時に, 人体の左右についている手は, 体の急所 (心臓) を守るのに近い左手が防衛という動作・働きを し，右手で相手を攻撃するという動作・働きを分 担したものという推察がある。この右手の攻撃と いう動作が，生き残るために左手の防衛よりも役 に立ったことから優位性, すなわち利きを勝ち取 り，利き手になったと考えられている1)。すなわ ち, 利き手は機能する手であり, 反対の手は支持 支援する手と言うことができると思われる。

右利き・左利きには, 利き手の他に, 利き足, さらには利き目, 利き耳という言葉もある。しか し, どうして利き手, 利き足などの働きの左右差 が生じるのかについての原因は定かではないとい

東邦大学医療センター佐倉病院耳鼻咽喉科
われてきた。

\section{1. 統計から見た人の左右差}

フィンランドにおける 30,161 人の利き手に関す る調查で, 18-69才の被検者で遺伝的な要因があ るかどうかについて調べた報告がある。左利きの 割合は, 一人子で $5.8 \%$, 双子で $8.1 \%$, 三つ子で $7.1 \%$ あ゙あ, 両手利きが一人子で $3.5 \%$, 双子で

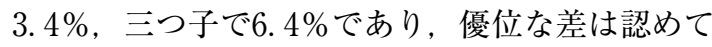
いない。しかし，小児期に左利きを右利きに家族 が強制的に変える効果は大きい結果であるとして おり，利き手は変えることができるということで あっだ。

\section{2. 右利き, 左利きと双生児}

一卵性双生览の中には，利き手が左右に分かれ ていたり，つむじが右巻き・左巻きと対称になっ たりする場合がある。このような左右対称の特徵 を多く持っている双子を，ミラー・ツイン（ある いはミラー・イメージ・ツイン）と呼ぶ。利用が 可能な日本人双生児の 2 大データベースを用い て, 双生児の利き手および利き足に関連する要因 を明らかにした報告がある゙”。双生児であること が影響を与えている可能性があるも，接合子体の 構造, 胎盤形成, 双子の誕生順序, 双生児の性別 等双生児に特有の利き手および利き足に関連する 因子は認められなかったとしている。しかし，性 別, 誕生年, 年齢, 経産回数, 新生児仮死, 在胎 期間, 出生時合併症, 家族歴等一般的な利き手や 利き足に影響を与える因子が，双生児であること よりも利き手や利き足に対してょり強い影響を及 ぼすとしている。 


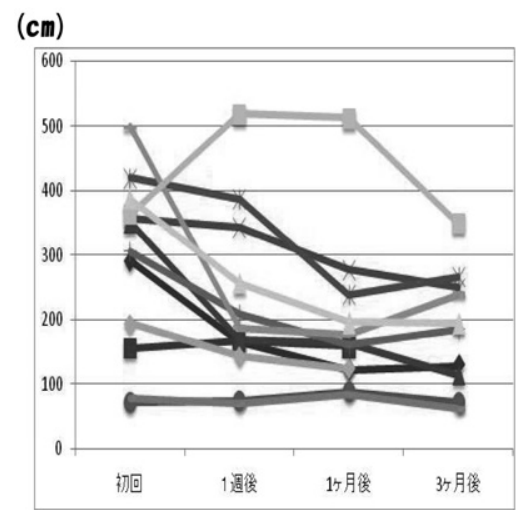

右前庭神経炎

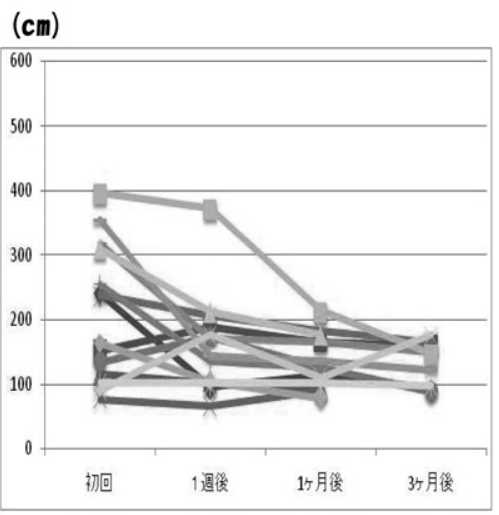

左前庭神経炎

図 1 総軌跡長の変化

\section{3. 右利き・左利きと脳磁図}

脳磁図を用いて左右脳半球における聴覚野の活 動を測定, 解析し, 左右の脳半球機能の違いにつ いて分析, さらに聴覚野反応と利き手, また言語 野との関連性についても分析した報告では, 脳磁 図を用いることにより，脳の活動を同時に左右脳 半球別に測定することが可能であり, 聴覚野の左 右脳半球活動差には利き手や言語野の局在が関連 していることが推察されたとしている4)。

\section{4. 利き手のクセと疾患}

利き手と異物の関係を調べた報告がある ${ }^{5)}$ 。2007 年12月から2008年 8 月の間に,「Aghia Sophia」 小児科病院（ギリシア）における46例の鼻内異物 と44例の耳内異物の検討である。鼻内異物と子供 の利き手には相関性は見られなかったが, 耳内異 物と利き手には有意差 $(\mathrm{P}=0.014)$ がみられたと している。

\section{5. 利き足・軸足}

利き手と同様に“利き足”がある。利き足は一 般的にはボールを蹴る足, 缶を踏みつける足, す なわち作用し器用に何かを作業できる動作をする 足と言われており，利き足の反対側が “軸足” と よばれる。軸足は，無意識に体重を支える支持足 である。あぐらや正座において下にあるのが軸足 といわれている。利き足も一般的には右が圧倒的 に多い。利き手が右の人は左足が軸足であること が圧倒的に多いわけである。

小学生の際に休めと号令をかけられ, 半歩なな
め前に足をだす動作があったが，これは軸足であ る左足で体を支えて，利き足である右足を休ませ る動作である。しかし，利き手と違って日常生活 をおくる際に不便さや不自由さなどを感じること は少ない。混雑した道路で, 前方から来る人とす れ違う際に, 多くはぶつからずによけていくもの である。しかし，時にすれ違いがうまくいかない でぶつかってしまったり，同じ方向によってお見 合いになってしまうことがある。右足が利き足の 人は，右に移動しようとする。左足が利き足の人 は左へ移動しょうとするため, 右足が利き足の人 と同じ方向へ移動することになるわけである。さ らに，右足が利き足で，左足が軸足であるという ことに関連しているのは, 野球やグランドトラッ クでの陸上競技の走り方が左回りであるというこ とは有名である。これは, 左足の軸足で外周上を なぞりながら走り，利き足である右足は蹴るとい う動作をするわけであり, 当然左足が軸足の人に 優位なわけである。

\section{6. 利き足と軸足に関連した疾病の検討}

これまで, 利き足・軸足の検討は, 整形外科領 域に多い。両足立ちや片足立ちによる重心図・接 地足蹠面積の検討では, 左足は右足より支持能力 が高い傾向があり，軸足として機能していると考 えられる ${ }^{6)}$ 。また, 階段昇降時の床反力前後方向 成分より制動力の左右差を比較検討した結果で は, 制動力は, 軸足での着地の方が利き足での着 地よりも大きいことを示すとしている7)。そのほ 


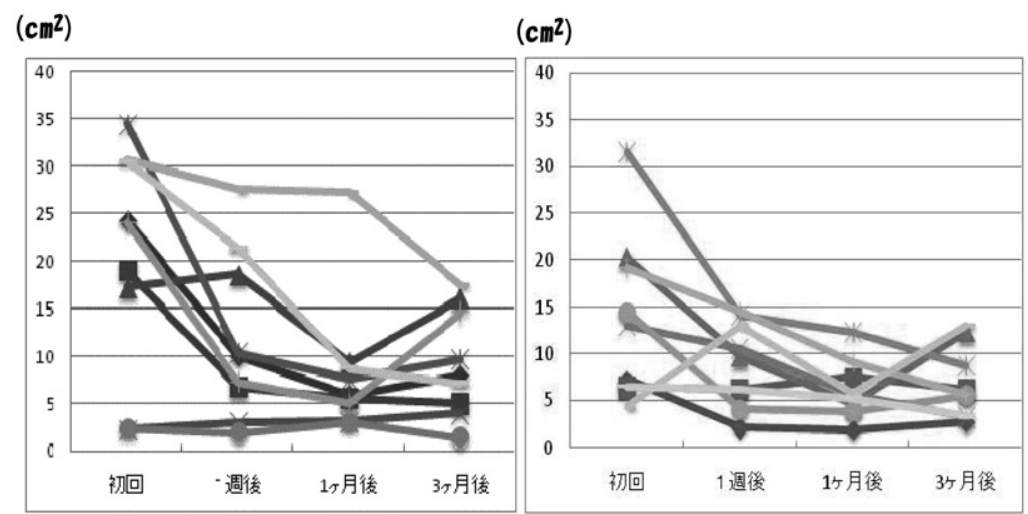

右前庭神経炎左前庭神経炎

図2 外周面積の変化

か，足圧中心の移動時間からみた利き足と軸足の 特性を調べた報告では，軸足から利き足への移動 時間は利き足から軸足への移動時間と比べて有意 に短く，しかも加齢による影響を受けにくく，一 方, 利き足から軸足への移動は加齿による影響を 受けやすい可能性を示唆している報告もある8

さらに，最近では変形性関節症（OA）464膝, 関節リウマチ（RA）161膝の合計625膝を対象に 手術適応側を調べた報告9) がある。OA では右210 膝, 左254膝で左の手術が多かった, RAでは右 69滕, 左92膝と左右差はなかったが, 全体では右 279膝, 左346膝で左が多かったとしている。また, どの群も男性には左右差はなかったが, 女性は左 が多かった。一般的に日本人の利き足は右側で, 左側は軸足・荷重肢と成るため生涯を通じて左側 の力学的負担は右側よりも多い。更に，女性の筋 力の対体重比は男性よりも低いため, 弱い筋力で は女性の膝関節の安定性は低下し, 軟骨・軟骨下 骨への動的力学負荷に耐え切れず，男性以上に変 性が進行すると推測していた。

\section{7. 体平衡から見た利き足の関係は…前庭神経炎 との関係}

軸足は，体重を支え姿勢の維持を役目としてい るので, 意識的に動かす利き足とは違って無意識 にコントロールされている足である。また，筋力 的にも優れている足である。それでは，めまいや 平衡失調の際にも，障害のサイドと利き足や軸足 は関係があるのではないだろうか……
私たちは，右前庭神経炎と左前庭神経炎の経過 の過程を比較検討した。前庭神経炎の発症後まも なく注視眼振が確認されている時期に初回の重心 動摇検查を行い, その 1 週間後, 1 ケ月後, 3 ケ 月後に検査を繰り返したものである。その結果 は，図 $1 ， 2$ に示したごとく，総軌跡長・外周面 積ともに右前庭神経炎に比べて左前庭神経炎の方 が早期に小さくなる，すなわち安定するという傾 向がみられた。これも，利き足・軸足との関係が あるのではないかと考えている。

\section{まとめ}

人だけでなく動物の世界でも右利き，左利きが あると言われる。これまで，右利きや左利きなど はヒトのクセ程度の解釈で,「右に直しなさい」 などと言われてきた。しかし，何故右利きが多い のかから端を発して, 左利きの能力など次第に学 問としてヒトの利き側が研究されるようになっ た。

私たちは，平衡に関わっている中であまり利き 側について論じられることは無かった。しかし， 利き側が姿勢の安定性や動きに影響することは, 非常に重要なことと考えられ興味を引く。とすれ ば，平衡に扔ける利き側については常に考慮され て考えていかなければならないと思われる。

\section{文献}

1 ）鮫島良文：あなたは完全な右（左）利き?? れとも○○利き? 11-13頁, 文芸社, 東 京, 2003 
2) Vuoksimaa E,Koskenvuo M,Rose RJ, et al.: Origins of handedness a nationwide study of 30, 161 adults. Neuropsychologia 47: 12941301, 2009

3 ) Ooki Syuichi: Nongenetic factors associated with human handedness and footedness in Japanese twin children. Environ Health Prevent Med 11: 304-312, 2006

4 ）山田奏子, 鈴鹿有子, 樋口正法 : 脳磁図を用 いた左右脳半球の機能分析に関する研究. 金 沢医大誌 $3: 235-244,2005$

5 ) Peridis S, Athanasopoulos I, Salamoura M, et al.: Foreign bodies of the ear and nose in children and its correlation with right or left handed children. Int J Pediatr Otorhinolaryngol 73: 205-208, 2009

6 ）三上一貴: 軸足・利き足の検討. 理療研 $16: 15-18,1999$

7 ) 松井祐介, 尾藤貴宣, 伊藤 譲, 他：利き足 軸足に関する研究（2）：床反力前後成分に よる検討. 柔道整復・接骨医学 $12: 275$, 2004

8 ）茅野慎一, 藪越公司, 濱田美希, 他: 足圧中 心の移動時間から見た利き足と軸足の特性. 運動療物理療 $13: 27,2002$

9 ）星野明穂, 張禎浩, 池田浩夫, 他：人工膝関 節手術は左に多いか?.日関節病会誌 27 : 119-122, 2008 